\title{
テラスハウスにおける子供の遊びの性格
}

正会員鈴木成 文* 正会員多胡進***
同 栗原嘉一郎** 同 $\bigcirc$ 溝神宏至朗***

\section{§1. はしがき}

文1では、T・H における子供の遊びを遊び場所を中

第 1 表遊び種類の分類

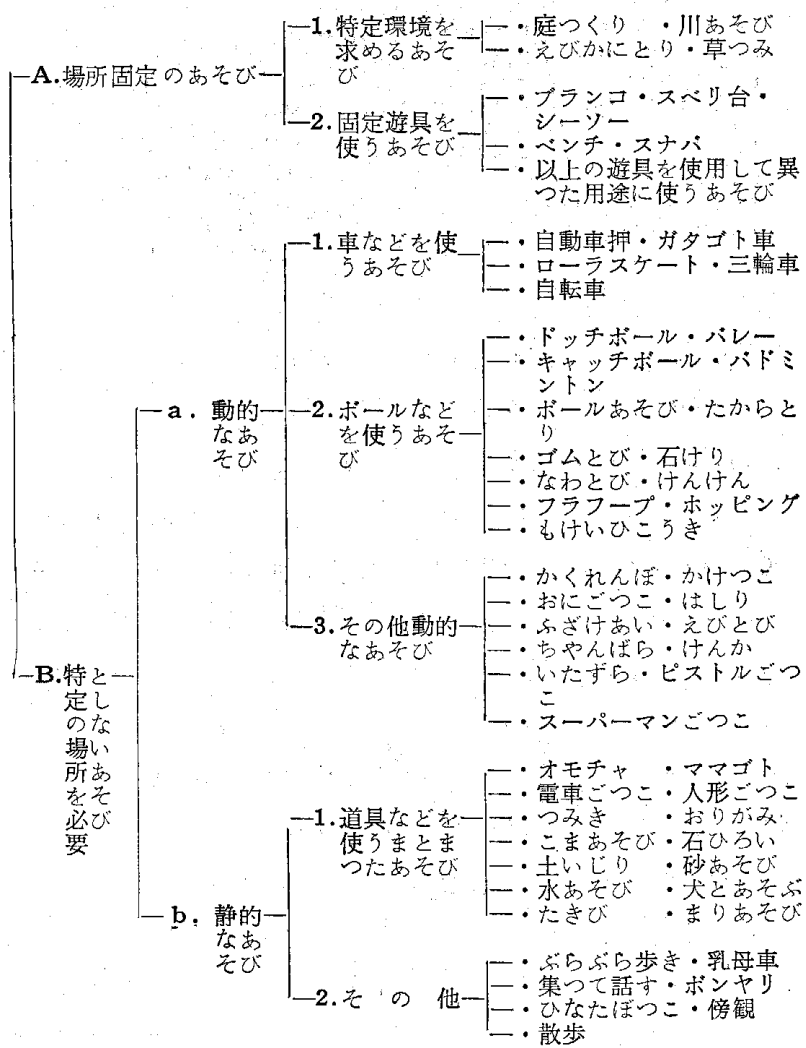

[中]

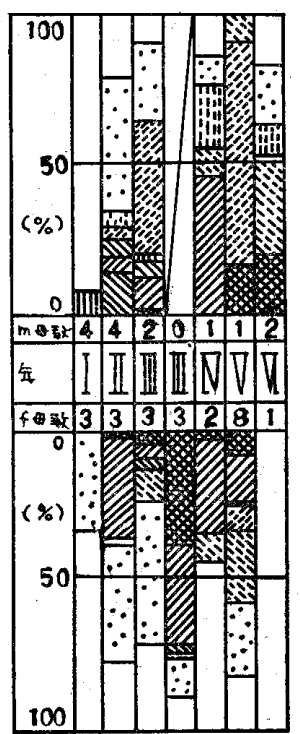

( $\left(\mathrm{A}^{\mathrm{a}}\right)$

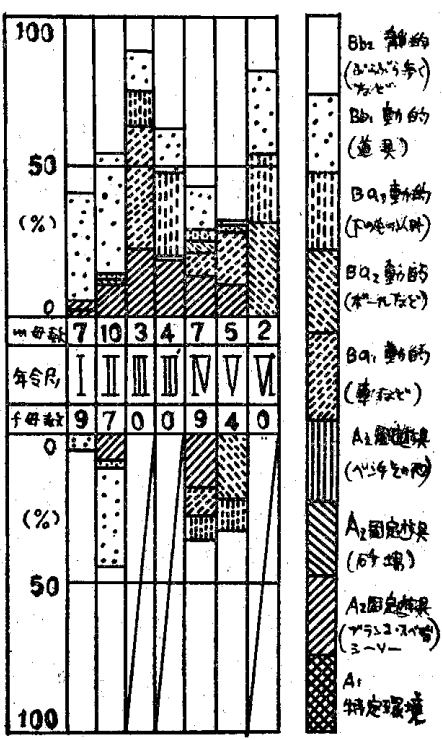

第 1 図遊 び種 類 時 間 率 (平均)

* 東京大学助教授 * * 大阪市立大学講師 工博

*** 大阪市立大学大学院生
心に考察した。とてでは文1に示した調査によつて更 に、配置空間の性格を知るために゙遊び種類”を考察し、 つぎに子供の遊び生活に大きな影響をもつ“遊びの同伴 者ならびに遊び仲聞”、ひいて教察し、最後に $\mathrm{T} \cdot \mathrm{H} の$ 計画にとつて重要な要素となる“任斐まわり”の問題に。 つて考察したい。

\section{§2. 年令別にみた遊びの種類}

第 1 表は、調查当日各団地で行なわれた遊びをスペー スに対する要求を軸として分類したものである。第 1 図 はこの分類にしたがつて、各年令層が行なつた遊び種類 を、遊んだ時間の割合で男女別に示したものである。

[I]層では、遊びこいえるものはほとんどみられな い。1才以下の乳母車・だつとなど ( $\mathrm{Bb} 2) 、 1$ 才以上 の土いじりなど(Bb 1)がわずかにみられる程度である。 [II]層では、小さな遊具を使う静的な遊び( $\mathrm{Bb} 2)$ 、とく にままごと・土いじりなどが多い。固定遊具を使つた遊 びもみられるが、3才以下では必らず付そいがいる〔中】 で多く、〔旭】が少いのは、前者はまず幼児遊園がつかい やすく、かつ保護してくれるものがいるためであらう)。 3 輸草類をもつた動的な遊び（Ba 1) もみられるが、こ れも3才以上であつた。[亚]層では、小遊具を使う静的 な遊び（Bb 1) が続くが、3 輪車・すもうなど、スペー スと床面の処理を考える必要のある遊び ( $\mathrm{Ba}$ )がとくに 男子においてあらわ机る。幼児遊園の固定遊具も 1 人で あるいは友だちとも使えるようになる。との層になる と、遊び種類・内容ともに豊富になるが、とくにこれ は、友だちと遊ぶ子供、幼児遊園で遊ぶ子供についてい 兑る。男女差も現われ始如て、男子は動的な遊びを好み。 だす。

[III]層では静的な遊びは娍少し、動的な遊び(A)(Ba) が増加する。グループ遊びも生ずるが、まだ一貫性のあ る遊びとならない。しかし友だちの影響は強く、〔旭つの [III'] [IV]層の遊び種類が貧弱なのはこの影響によると 思われる。[IV]層では学校へ通い始めるため、友だちと ともに行なう遊び（Ba）が多くなる。幻児遊園の固定遊 具もよく使われ、男子で梳融通性のある使い方をしだ す。かくれんぼ・おにごつとなどは男女とも好むが、男 女差はさらに表われ、男子はスーパーマンごつこ・ちゃ んばら・ピストルなど、女子は石けり・けんけん・まり つき・固定遊具の素直な使用などをよく行う。[V]層で は男子と女子で遊び方は大きく変る。女子はまだ固定遊 
具を使うが、それはぶらんこなどで運動量は大きい。ま た女子は、友だちとの遊びも、ドッチボール・ゴムト ビ・けんけんのような Ba 2 の種類が眼につき、1ケ所 でルールのある遊びをする。もちろんとの中に男子が入 るとともある。男子は幼児園へいっても、殆んど固定遊 具は使わず、とくに好むのは友だちとの高度に組 織的 な、活発な遊び種類となる。この年令では融通性、持続 性、一貫性がみられる。[VI]注学校からの帰宅時間が遅 いためにあまり遊ばないが、時々弟や妹の遊びに加わつ たり、小学生とバドミントンなぞを行うことがある。

〔旭〕と〔中〕をくらべると〔旭〕は遊び種類が各年令とも 少く単調であり、何もせずボンャリしている $\mathrm{Bb} 2$ が多 い。子供の遊びに適した配置空間としては〔中〕の方が 親しみがあると思われた。

\section{§1. 遊び場所と遊び種類}

第 1 表の遊び種類がどのような場所で展開され、どの ような性格のスペースと結びついてくかを、時間・回 数・実人数でとつたものが第 2 図である。てれらからつ ぎのととが考察される。

各戸の庭 : 各年令層とも何らかの形で庭で遊ぶ。その うちでもとくに静的な遊び $\mathrm{Bb} 1$ が行なわれる。[I]層 では、母親に見守られて日向ぼつてや土いじり $(\mathrm{Bb})$ ， [II $] \cdot[$ III] 層は室内遊びの延長としてままごとや砂あそ びなど（Bb 1) を行なう。また、てれらの遊びにおい て、オモチャ・3 輪車がよく置きはなしにされる。との ように $[$ III] $]$ 圆以下の子にとつて庭は重要な遊び場であ る。3才以上になると、前後楝の他人の庭へてれらをも ちとむとともある。また、 $\left[\mathbb{I I}{ }^{\prime}\right] \cdot[\mathrm{IV}] \cdot[\mathrm{V}]$ 層の数人で 行う動的な遊び（Ba)，すなわちたからとり・ちやんば ら・石けりなどがもちてまれることがある。この場合、 遊びがきゆう屈になり、庭がせますぎて混乱する。子供 がよく遊んでいる庭では植栽もなく、物を置く部分が少 しあるのみの場合が多いのはての結果と思觉る。庭は避 びの他に各家族のリビング的スペース・サービススペー スなどの機能をもつので一面的にはきめられないが、出 来るならサービススペースと分離する、棟の通り抜けな ど考え、更に子供の遊びをのばすよう若えたい。

棟まわりのスペース:[III]層以下では庭での遊びの延 長としての静的な遊びは各戸周辺の棟まわりで行なわれ るととが多い。動的な遊び（Ba）はいろいろあるが、舗 装されたアプローチでは 3 輸車遊びが盛んである。ボー ル遊びはスペースを要求するから他に広い所（オープン スペースやパーキング）がある場合はそてに移る。妻間 の空地でバドミントン等の行なわれるとともある[香】・

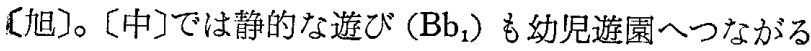
が、一方〔旭つでは幼坚遊園と結びつきにくい住戸が多い ために、棟まわりでの遊び種類は多く、しかもそのほと んどはててで完結してしまう。いずれにしてる棟まわり

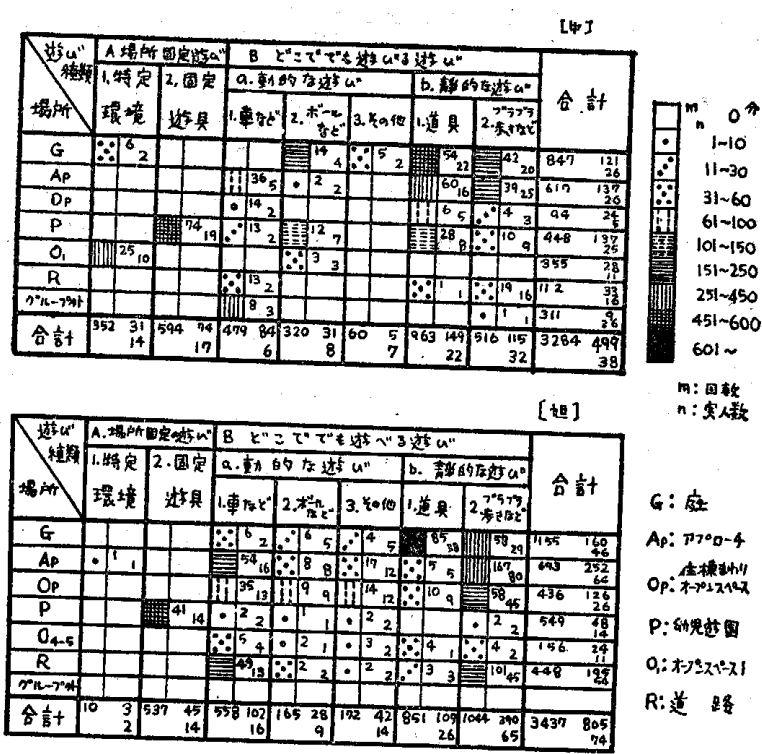

第 2 図遊び場所と遊び種類

は静的な遊び、動的な遊びともに行なわれる。

幼児遊園：［II]層以下で注住戸との結びつきが良い場 合注庭での静的な遊びがこてまで延長されることがあ る。特に [II]凮は住戸と幼児遊園が接する時や兄姉等の

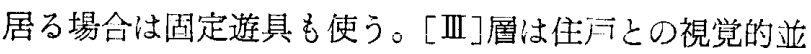
びに距離的な近づき易さが幼坚避園の利用に強い影響を 与える。遊具の使い方は素直で、ブランコが最も好まれ 以下杪場・スベり台・シーソーの順である。[亚' $] \cdot[N]$ 䍹はブランコ・スベリ台をよく使うが $[I V]$ 風は男女で使 い方も変る。男子は遊具を中心に㥞々な遊びを展開する が女子はブランコを素直使う。[V]層になると男子は 遊具を使うというよりむしろスペースを利用して行う動 的なグループ遊び $(\mathrm{Ba})$ を行う。女子も1ケ所にまとま つたグループ遊び $\left(\mathrm{Bb}_{1}\right)$ を行う。しかし幼児遊園に才 ープンスペースがなく、他にスペースのあるパーキング がある場合 (〔旭】) や他のグループの幼児遊園に友だち がいる場合やオープンスペースのある場合は乞ちらに流 れる。次江各団地を比較すると〔中〕は棟に围まれて住 戸との結びつきもよく算围気にまとまりがあり、遊びの 種類も内容も豊かである。〔香〕は道路や高低差のために 雾团気が乱され易い。空地がないためにスペースを求め る遊びは周边道路で行なわれる。「迏】では広い道路のた めに落着きを欠き、かつ住楝まわりから遊びは自然に延 長しない。遊びの種類も内容も単調で安定せず、遊具も 殆んど素直な利用に終つている。

道路：ててでは主にアプローチだけでは収まらない自 転車遊びなどが多いが、グループ内に適当な空地がない 場合は $[\mathrm{IV}] ・[\mathrm{~V}]$ 層の動的なグループ遊びも道路やグ ループ外へ延びる。

オープンスペースその他：草つみ・虫とり $\left(\mathrm{A}_{1}\right)$ など のできる場所はよく使われる([中])。即ち、小川やク口 ーバのあるオープンスペースでは遊びを自由に展開す 

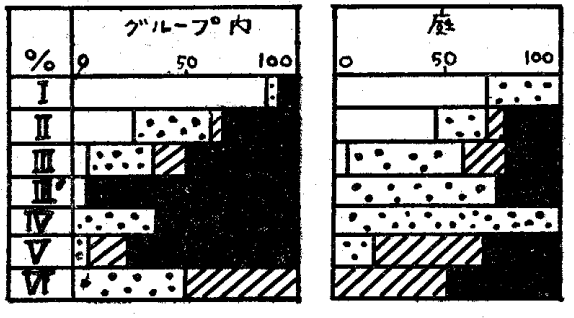

保 $z^{\prime \prime}$ 者。

第 3 図

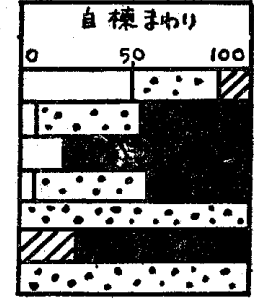

$\because \cdot 9$

場 所

る。しかし、魅力に乏しい所では遊ばれていない(旭】・

〔中〕のその他のオープンスペース)。

\section{§ 4. 遊びの同伴者ならびに遊び仲間}

1。 戸外生活における子供の自立性 : 第 3 図 グループ外：[II] 層までは必ず保護者がついて出る。 [III]層方らは友達や兄姉と出办けはじめる。 $[\mathrm{IV}] ・[\mathrm{~V}]$ 層柱全く保護者党必要としない。

グループ内：[I]凮は保護者がついているが、1才以 上は棟まわりまでは 1 人遊びをひろげるてともある。 [II]層はほとんぞ自立して遊ぶようになり、1人遊びの 率が高くなる。幼児遊園には保護者や兄姉がついてい く。[III]風になると自由に 1 人で遊べるが庭以外のとて では友達との遊びの率が高くなる。[亚' $] \cdot[I V]$ 層は保護 者を必要とせず友達を積極的に求め始める。相手がい いと遊びは伸びなくなる。[V]廉は必ず友達とグループ を組んでいるが、庭や棟まわりでは 1 人で遊んだり年下 の兄弟と遊んだりするととも多い。

\section{$2 \circ$ 友達の形成範囲}

第 4 図は子供が調查当日一緒に遊んだ仲間の住戸の分 布状態を示すものであり、例えば〔中〕 33 号一 1 の子供 と33号-2 の子供が遊んでいるととを示す。友達の形成 範囲は以下に述べるように、文 1 亿おける子共の遊びの 生活圈とほぼ重なつているととが判るが、同時に年令・ 配置技法などによつても異る。

[II] 層位では同棟、前後棟の友達と遊びはじめ、やが て遊びをひろげていく。

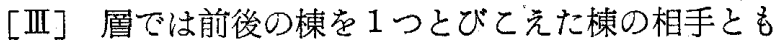
遊ぶようになる。[III]・[IV] 層になると自棟中心に 8 10棟位の範囲にひろがる。[V]層では、グループ内では $\left[\mathbb{I I}^{\prime}\right] \cdot[\mathrm{IV}]$ 層とほぼ同じであるが、グループ内の友達に 加えて学校友達と遊んでいる。

各団地の遊び仲間の範团をみると次のようになる。

〔中]では $[I] \sim[\mathrm{III}]$ 層は同棟及び前後 $3 \sim 4$ 棟で仲 間を作る。[III']・[IV] 層では友達範囲はグループ全域に 達している。南端に孤立する 25 号棟は友達を得にくい。 [V]層ではたまたまグループ内に女子が多かつたのでま とまりがあつたが男子ではグループという単位が少し小 さいと考えられる。しかし全年令層を通じてまとまりが ある。〔香]では [III] 層以下㥀路で遊び仲間はきられ
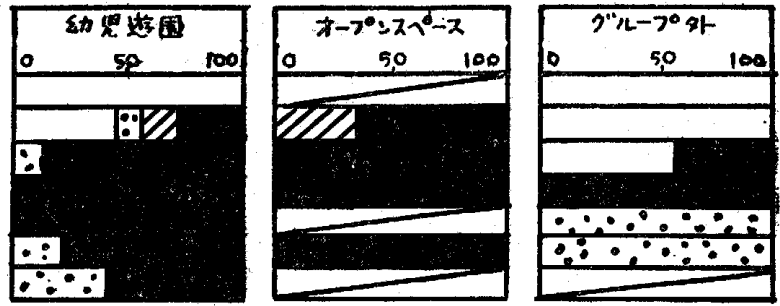

i $人$ WZA 只弟

友连

別同伴 者

てしまう。[亚’］風以上で時たま融合するが安定性に之 しい。特に東西の兩端の棟の子供は結びつかない。【旭】 は各年令層ともにアプローチを単位とした $4 \sim 5$ 棟の狭 い範国瑯られ、グループは 4 つに分けられてしまう。 道路をへだてた住居群の子供とは遊んでいない。

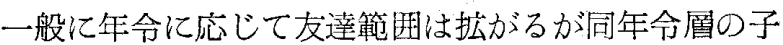
供のいる住戸との距離が遠かつたり、道路やがけなど心 理的障害になるものがあったりすると友達範目は狭くな る。孤立した棟は［亚］層以下に不利である。また幼児遊 園と住戸との結びつきが悪い場合は $[$ III]風以下の友達形 成に不利である。遊びを構成する友達人数は遊び種類や 場所によつて变るが、[III]㕌以下では $2 \sim 3$ 人、[III']・[IV] 㜿では $3 \sim 5$ 人、 $[\mathrm{V}]$ 層では $3 \sim 8$ 人位である。

$\S 5$. 住戸への出入り : 第 5 図

住戸への出入りは南北両面か使われるが一般に遊びの 時は南側の居間からの出入りが多い。しかし、配置の条 件即ち自分に適した遊び場所との位置関係、友達の分 布、周囲の環境などによつて変る。〔中〕を例にとつてグ ループ北側の 32 ・39・40号棟をみると、32・39号棟は南 からの出入りの多いのに対して、40 号棟では北側からの 出入りもかなりあり南から出ても妻側を通つて北側にま わるものもみられた。とれは 40 号棟がグループ内の幼 児遊園よりも北側のポイントの棟のグループの幼坚遊園

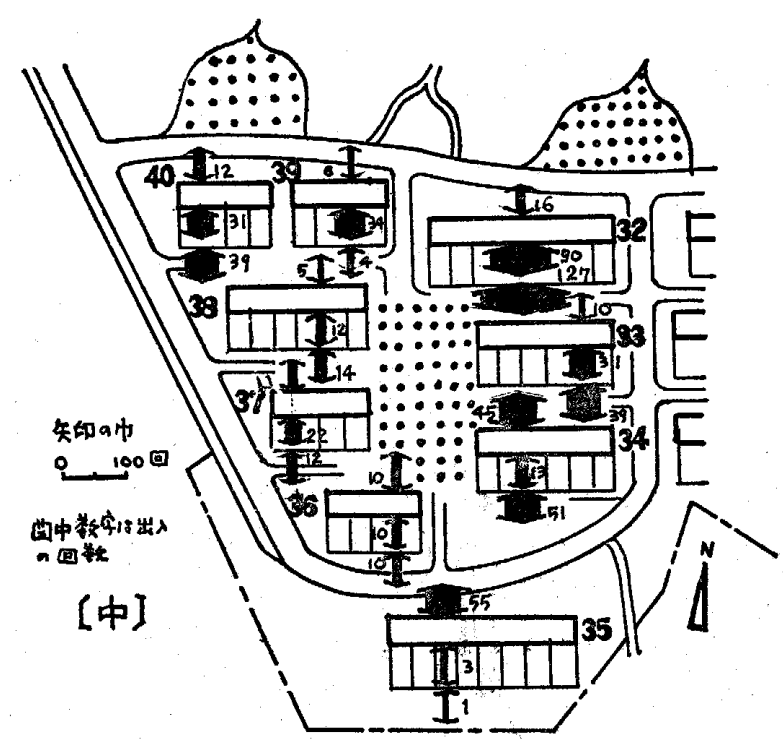

第 5 図友達の形成 


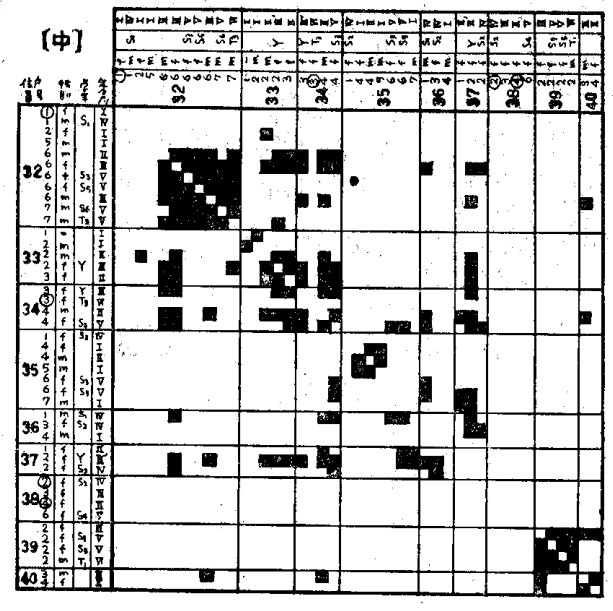

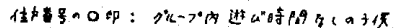

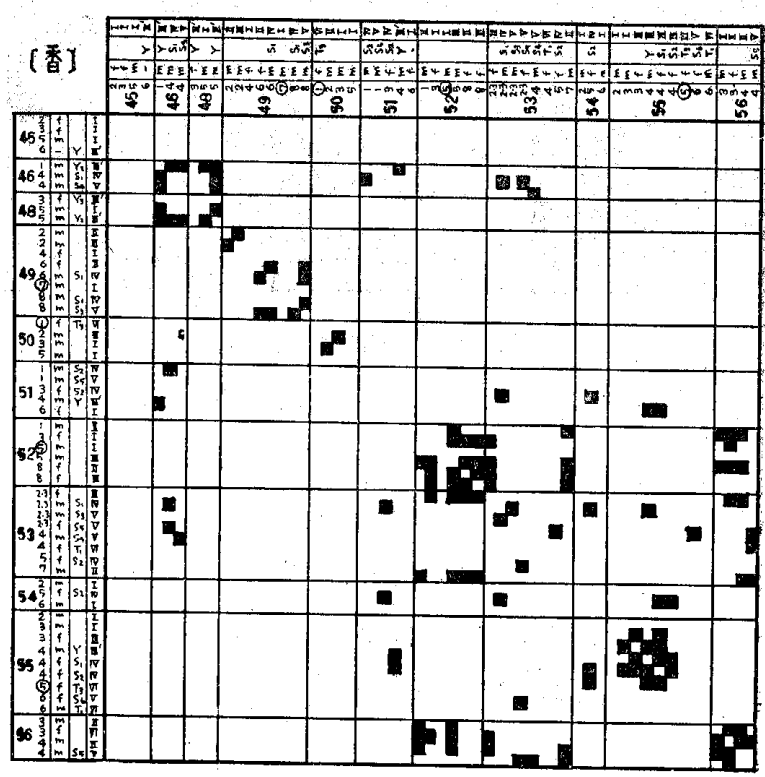

第4図友達の形成範，囲

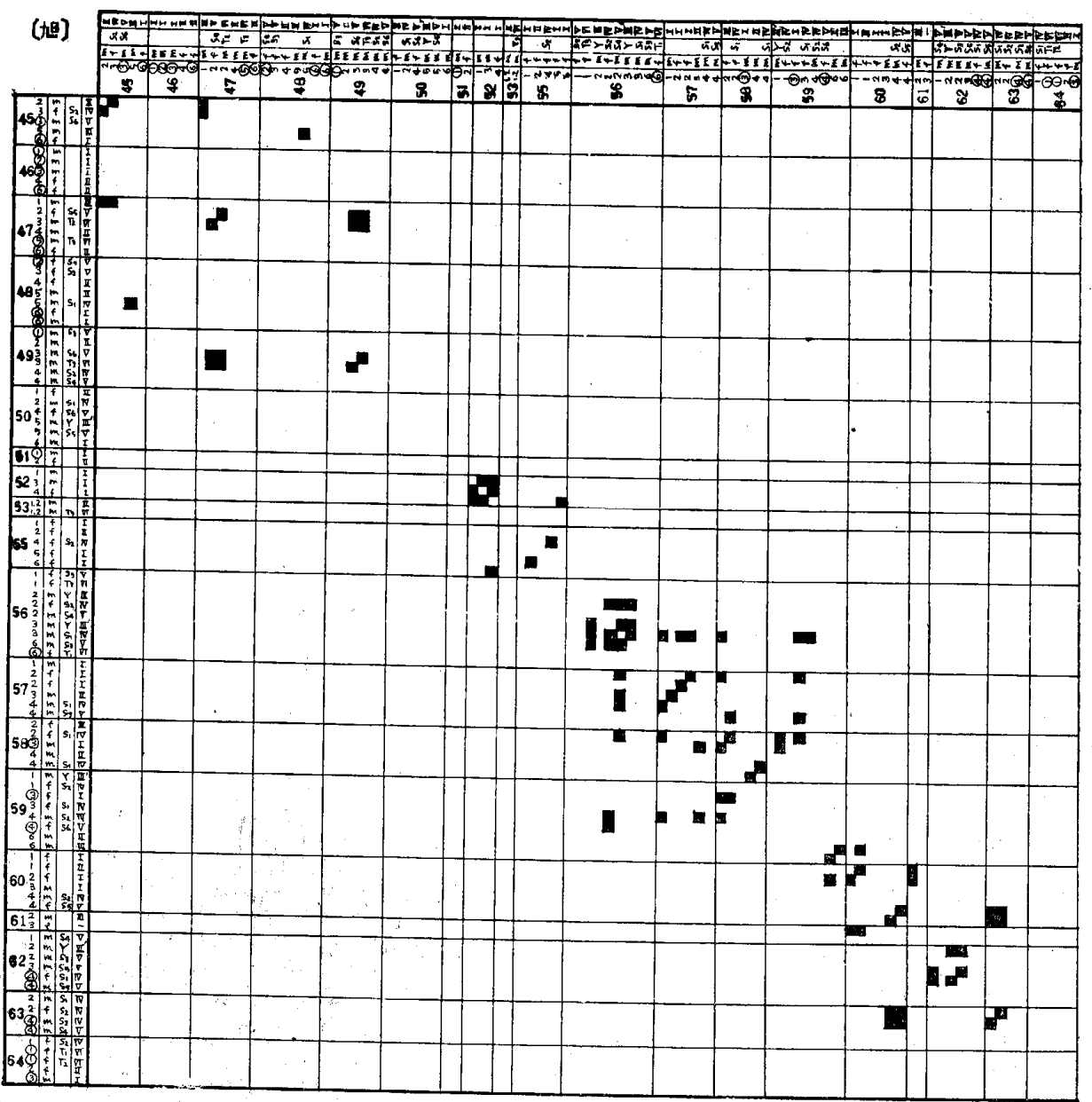

第 4-2 図出 入 頻度

との結びつきがよく、また 38 号棟に友達がないため にその方へ流れると思われる。34号棟では[III]層以下だ けではまだオープンスペースを使うととが出来ず北側の 落着いたアプローチが適しており、更に33 号棟には友 達がいたために北側からの出入りが多くなつている。35 号棟も北側からの出入が多く、庭にもあまり出ない。乙 れは南が広漠とした田畑であり庭らしい雲囲気がないか
らであると思われる。

以上のように日常の遊びのための出入りは玄関に関係 なく配置の条件によつて変るので、玄関の向きは出入頻 度よりも居間や庭の利用などから決定すべきであろう。

[注］文 1 : テラスハウスに安ける子供の遊び場所 : 昭 36 年10 月 大会論文 (第 69 号): 鉿木成文ほか 